\title{
Cultivation of Oyster Mushroom (Pleurotus florida) on Wheat Straw Supplemented with Wheat and Rice Brans
}

\author{
Hemanth Kumar Ganjikunta*, S. Simon, Abhilasha A. Lal and R. A. Bhuvanesh \\ Department of Plant Pathology, SHUATS, Prayagraj, 211007 (U.P.), India \\ *Corresponding author
}

\section{A B S T R A C T}

\begin{tabular}{|l|}
\hline Key w o r d s \\
$\begin{array}{l}\text { Oyster mushroom, } \\
\text { Wheat and rice } \\
\text { brans, Biological } \\
\text { efficiency, Benefit } \\
\text { cost ratio }\end{array}$ \\
\hline Article Info \\
\hline $\begin{array}{l}\text { Accepted: } \\
16 \text { November } 2020 \\
\text { Available Online: } \\
\text { 10 December } 2020\end{array}$ \\
\hline
\end{tabular}

The research experiment was carried out using the wheat and rice brans with wheat straw to evaluate the growth and yield parameters of oyster mushroom (Pleurotus florida). The brans were evaluated in combination with wheat straw (wheat straw + wheat bran $20 \%$, wheat straw + wheat bran $15 \%$, wheat straw + wheat bran $10 \%$, wheat straw +rice bran $20 \%$, wheat straw +rice bran $15 \%$, wheat straw +rice bran $10 \%$ and control -wheat straw). The objective of this study was to find out best bran percentage supplemented that support the growth of oyster mushroom, produces maximum yield with highest biological efficiency (\%). In total seven treatments are replicated six times under completely randomized design. The minimum time taken for complete spawn run (13.67 days), primordial initiation (19.50 days), fruiting bodies formation (20.83 days); maximum yield (450.99 $\mathrm{g} / \mathrm{kg}$ wheat substrate), biological efficiency (274.10). Yield and biological efficiency were enhanced by wheat bran and the latter rice bran less suitable.

\section{Introduction}

Mushrooms are fleshy, spore-bearing reproductive structures of fungi grown on organic substrates and for a long time, have played an important role as a human food due to its nutritional and medicinal properties (Etich et al., 2013). Mushrooms are magic living organisms and need very few things to grow. In the present conception, a fungus species is considered edible, if eating causes no health disorders. Cultivated and wild mushrooms are a good source of protein, vitamins, minerals, carbohydrate and fibers and are known to have a broad range of uses both as food and medicine. Furthermore mushrooms are low in calories, sodium, fats and cholesterol. Edible mushrooms have long been considered to have medicinal value and to be devoid of undesirable effects.

Over 200 species of mushrooms have long been used as functional foods around the world, but only about 35 species have been commercially cultivated. Today China is leading in global mushroom production in cultivation of edible and non-edible mushrooms. China produces approximately $70 \%$ of world mushroom production. The second highest mushroom producing country is USA, followed by some European countries. Cultivation and production of 
edible mushrooms increased particularly in America and Asia (Karthick and Hamsalakshmi, 2017). India has got 16th rank as per 2013 reports. Per capita consumption of mushroom in India is currently about $25 \mathrm{~g}$ per year. The natural advantage of mushroom cultivation in India is due to the presence of seasonal variation, abundance and availability of variety of agro wastes at low prices.

The fungus Pleurotus is also known as oyster mushroom. It is a macro fungus with a distinctive fruiting body is unique biota which assembles its food by secreting degrading enzymes. Pleurotus sp. belongs to the phylum: Basidiomycotina, class: Agaricomycetes, family: pleurotaceae. Their increased nutritional importance is due to the nutritive value of high grade mushrooms, which almost equals that of milk (Chang et al., 1991). Cultivation of oyster mushroom was initiated in Germany in 1917 on tree stumps and wood logs. Pleurotus sp. are popular and widely cultivated throughout the world mostly in Asia and Europe owing to their simple and low cost production technology and their higher biological efficiency (Mane et al., 2007). It enables us to obtain substrate material at low price or even for free and to conserve our surrounding by recycling wastes. It has also played an active role on purifying polluted soil from heavy metals and crude oil (Emuh et al., 2010).

Pleurotus florida is characterized by a white spore print attached to decurrent gills, often with an eccentric (off center) stipe, or no stipe at all. Stanley et al., (2011) reported a high nutritional values of $P$. florida with protein (25-50\%), fat (2 - 5\%), sugars (17 - 47\%), mycocellulose $(7-38 \%)$ and minerals (potassium, phosphorus, calcium, sodium) of about $8-12 \%$. They also possess a number of medicinal properties, such as antitumour, immunomodulatory, anti-genotoxic, antioxidant, anti-inflammatory, hypo- cholesterolaemic, anti-hypertensive, antiplatelet-aggregating, anti-hyperglycaemic, antimicrobial and antiviral activities (Gregori et al., 2007).

In terms of world mushroom production, Pleurotus sp rates second, after Agaricus bisporus, accounting for $25 \%$ of total world production of cultivated mushrooms. There has been significant increase in production of mushrooms in the last few years, especially of the oyster and paddy straw mushrooms in India. The present production status revealed that, Maharashtra and Odisha are emerging as the leading states in mushroom production. By considering the present production data, mushroom industry in India recorded an average annual growth rate of $4.3 \%$. During this period, the productivity has raised from $20 \%$ to $24.5 \%$. The global mushroom industry has expanded very rapidly in the last two decades by the addition of newer types of mushrooms for commercial cultivation. Despite of favourable agro-climate, abundance of agro wastes, relatively low-cost labour and a rich fungal biodiversity, India has witnessed a lukewarm response in its growth. In the year 2016-2017, Indian mushroom industry generated revenue of Rs. 7282.26 lakhs by exporting 1054 quintals of white button mushroom in canned and frozen form. By considering the production statistics, the spawn demand in India is estimated about 8000-10000 tons per annum.

Recycling is the need of modern times and cultivation of oyster mushroom is an ideal candidate to harness its potentialities. The spent mushroom substrate is the leftover of wastes after different flushes of mushroom have been harvested. These growing substrates may be composed from different wastes material such as sawdust, rice straw, cotton wastes, paper wastes, cocoa shells, wheat straw, maize husks and various other wastes. 


\section{Materials and Methods}

The experiment was carried out in the Mushroom Crop Room and Research Laboratory, Department of Plant Pathology, SHUATS, Prayagraj, 211007 (U.P.), India during the period from October 2019 to January 2020. the base substrate locally availabl wheat straw (Triticum aestivum) supplemented with brans of wheat (Triticum $s p p$ ) and rice (Oryza sp) ate collected from local area. Spawn of Pleurotus florida was procured from Chandra Shekhar Azad University of Agriculture and Technology Kanpur, U.P., India.

\section{Experimental design}

In this experiment, the base substrate wheat straw was supplemented at different rates i.e. $0 \%$ (control), $10 \%, 15 \%$ and $20 \%$ with wheat bran and rice bran respectively. Each treatment have 6 replicate, resulting in 42 experimental units. The effects of these experimental conditions were evaluated by their effect on complete span run period, time (days), primodial formation yield and biological efficiency (BE) of Pleurotus florida

\section{Substrate preparation}

Wheat straw was used as the base substrate for all the treatments. The straw was sun dried and cut into small pieces $(2-3 \mathrm{~cm})$. Fifty liters of tap water was filled in a plastic drum of 100 liter capacity. A solution was prepared with formaldehyde $(50 \mathrm{ml})$ and carbendazim $(7.5 \mathrm{~g})$ in water (Sohi, 1987). This solution was stirred properly with a stick for and the dry wheat straw substrate was slowly steeped completely in the solution. The mouth of the plastic drum was sealed with the lid and kept for 16-18 hours. After sterilization, the straw was taken out and the excess water was drained and spread out as thin layer on sterilized plastic sheet spread or on cemented floor in a shaded area. The straw was left for 2-3 hours to get (60-65\%) moisture capacity which is checked by taking a handful of straw and squeezing tightly if water does not drip from the substrate and it is moist, the substrate is ready for spawning.

\section{Cropping and harvesting}

Inoculated bags were incubated in dark room in a temperature maintained between $26 \pm 2^{\circ} \mathrm{C}$ by using electric heater. Humidity was maintained between $80-85 \%$ by spraying water thrice a day on gunny bags which is clip on the walls and the floor of the mushroom crop room. The inoculated bags kept in cropping are to attain the five stages of mushroom growth: spawn run, primordial initiation, stalk formation, cap differentiation and maturation. To regulate the oxygen and carbon dioxide levels, the crop room was opened for 1-2 hours every day.

\section{Statistical analysis}

In the present study, completely randomized design (CRD) was applied for the analysis of the recorded data. The conclusions were drawn on the basis of analysis of variance (ANOVA). The calculated $\mathrm{F}$ was compared with the tabulated 5\% level of probability at the appropriate degree of freedom (Fisher and Yates, 1986).

\section{Results and Discussion}

\section{Effect on combinations of wheat straw and supplements}

The study was conducted to evaluate the best combination of media in stimulating the growth of Pleurotus florida so that the productivity improved. Locally available wheat straw and brans were mixed in different (100, 90: 10, 85:15 and 80:20) inoculated in 
4\% spawn level. The findings reveal that, supplemented bags at different concentrations, have better results in terms of growth stages and yield than the one without supplementation. Among two supplements
(WB and $\mathrm{RB}$ ) at variable, concentration rates (10\% and $15 \%$ and $20 \%$ ), wheat bran (WB) show superiority than rice bran $(\mathrm{RB})$ then comes without supplementation wheat straw alone (Fig. 1 and Table 1).

Table.1 Effect on combinations of wheat straw and supplements doses on growth cycle and yield of Pleurotus florida

\begin{tabular}{|l|c|c|c|c|c|c|}
\hline Substrate combinations & $\begin{array}{c}\text { Supplement } \\
\text { Ratio (\%) }\end{array}$ & $\begin{array}{c}\text { Spawn } \\
\text { run } \\
\text { (Days) }\end{array}$ & $\begin{array}{c}\text { Primordia } \\
\text { initiation } \\
\text { (Days } \\
\text { from } \\
\text { spawning) }\end{array}$ & $\begin{array}{c}\text { Maturation } \\
\text { of fruiting } \\
\text { body (Days } \\
\text { from } \\
\text { spawning) }\end{array}$ & $\begin{array}{c}\text { Yield } \\
\text { (g/kg) }\end{array}$ & BE (\%) \\
\hline Control - Wheat straw & $(100 \%)$ & 16.00 & 26.50 & 27.33 & 334.10 & 140.62 \\
\hline Wheat straw +wheat bran & $(20 \%)$ & 13.67 & 19.50 & 20.83 & 450.99 & 164.22 \\
\hline Wheat straw +wheat bran & $(15 \%)$ & 14.50 & 22.17 & 22.83 & 406.67 & 160.08 \\
\hline Wheat strew +wheat bran & $(10 \%)$ & 14.17 & 21.67 & 23.00 & 378.18 & 156.61 \\
\hline Wheat straw +rice bran & $(20 \%)$ & 17.51 & 22.50 & 23.83 & 372.18 & 154.43 \\
\hline Wheat straw +rice bran & $(15 \%)$ & 18.67 & 20.17 & 23.17 & 333.60 & 162.44 \\
\hline Wheat straw +rice bran & $(10 \%)$ & 18.50 & 22.17 & 24.50 & 331.99 & 137.36 \\
\hline CD(at5\%) & & 0.81 & 2.306 & 2.97 & 23.506 & 17.8 \\
\hline
\end{tabular}

Fig.1 Effect on combinations of wheat straw and supplements doses on growth cycle and yield of Pleurotus florida

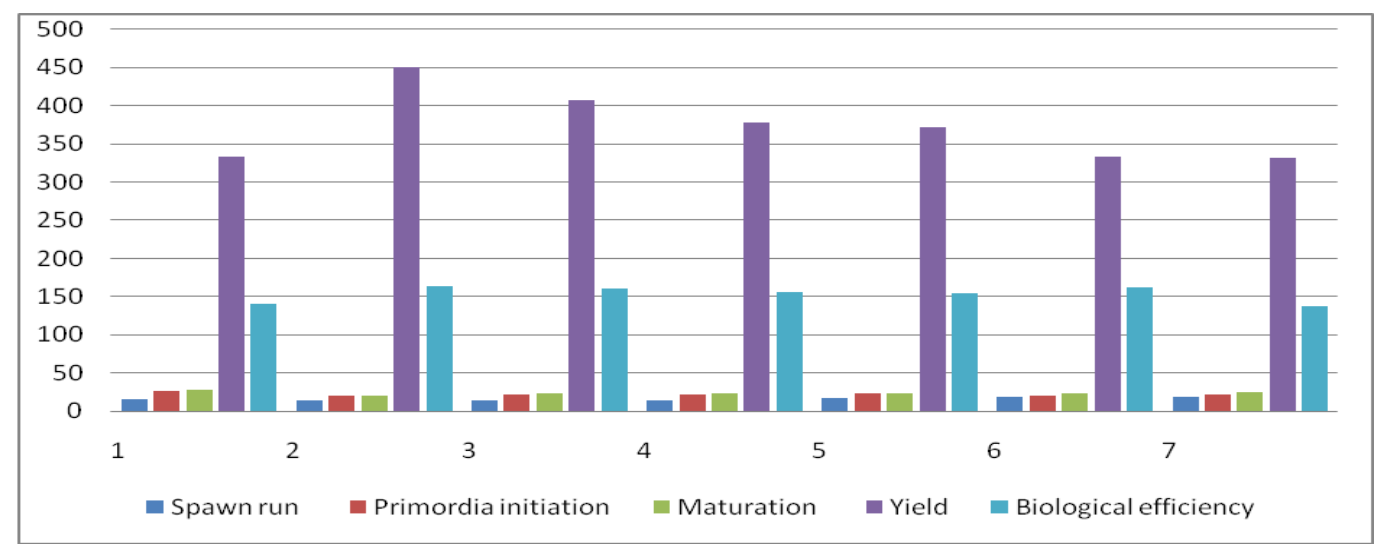

The maximum yield was recorded in $\mathrm{T}_{1}$ wheat straw + rice bran at 20\% (450.99 g) followed by $\mathrm{T}_{2}$ wheat straw + wheat bran at $15 \%$ $(406.67 \mathrm{~g}), \mathrm{T}_{3}$ wheat straw + wheat bran at $10 \%(378.18 \mathrm{~g}), \mathrm{T}_{4}$ wheat straw + rice bran at $20 \%$ (372.18 g), $\mathrm{T}_{5}$ wheat bran + rice bran at $15 \%$ (333.60 g), $\mathrm{T}_{6}$ wheat straw + rice bran at
$10 \%$ (331.99 g), respectively as compared to control $\mathrm{T}_{0}$ wheat straw $(334.10 \mathrm{~g})$. from a total of three flushes. The minimum time taken for complete spawn run (13.67 days), primordial initiation (19.50 days), fruiting bodies formation (20.83 days) biological efficiency (274.10).As per findings of Rosy 
and Schisler, Zang et.2014 and Kitamoto et al.1995, the increase in yield of mushroom supplemented with brans can be attributed to the carbohydrates, amino acids and mineral elements in the supplements and also nitrogen content helped in improvement of yield which was the case in wheat bran supplementation.

\section{References}

Chang, S.T., Lau, D.W. and Cho, K.Y. (1981). The cultivation and nutritional value of Pleurotus sajor-caj. European Journal of Applied Microbiology and Biotechnology 12: 58-62.

Etich, O. K., Nyamangyoku, O. I., Rono, J. J., Niyokuri, A. N. and Izamuhaye, J. C. (2013). Relative performance of oyster mushroom (Pleurotus florida) on agroindustrial and agricultural substrate. International Journal of Agronomy and Plant Production 4: 109-116.

Emuh, F. N. (2010). Mushroom as a purifier of crude oil polluted soil. International Journal of Science and Nature 1: 127132.

Fisher, R. A. and Yates (1968). Statistical method for research workers. Oliver and Boyd ltd, Edinburgh and London. 10.

Gregori, A. S., Vagelj, M. and Pohleven, J. (2007). Cultivation techniques and medicinal properties of Pleurotus florida. Food Technology and Biotechnology 45: 238-249.

Fisher, R. A. and Yates (1968). Statistical method for research workers. Oliver and Boyd ltd, Edinburgh and London. 10.

Karthick, K. and Hamsalakshmi (2017).
Current scenario of mushroom industry in India. Internatinal Journal of Commerce Management Research 3(23): 47-73

Kitamato, Y., Horkoshi, T., Hosio, N. and Ichikawa, Y. (1995). Nutritional study of fruiting body formation in Psilocybe panaeoliformis. Transactions of Mycological Society of Japan 16(3): 268.

Royse, D. J. and Schisler, I. C. (1986). Cultivation of shitake on supplemented sawdust. Shiitake News 3: 4-4.

Mane, V. P., Patil, S. S., Syed, A. A. and Baig, M. M. (2007). Bioconversion of low quality lignocellulosic agricultural waste into edible protein by Pleurotus sajor-caju (Fr.) Singer. Journal of Zhejiang University 8: 745-751.

Sohi, H. S. (1987). Diseases and competitor moulds associated with mushroom culture and their control. Extension Bulletin 2: 10-12.

Stanley, H. O. and Odu, N. N. (2012). Cultivation of oyster mushroom (Pleurotus tuber-regium) on selected organic waste. International Journal of Advance Biological Research 2: 446448.

Zhang, R. Y., Hu, D. D., Ma, X. T., Li, S. G., $\mathrm{Gu}, \mathrm{J} . \mathrm{G}$. and $\mathrm{Hu}, \mathrm{Q} . \mathrm{X}$. (2014). Adopting stick spawn reduced the spawn running time and improved mushroom yield and biological efficiency of Pleurotus eryngii. Scientia Horticulturae 17(5): 156-159.

\section{How to cite this article:}

Hemanth Kumar Ganjikunta, S. Simon, Abhilasha A. Lal and Bhuvanesh, R. A. 2020. Cultivation of Oyster Mushroom (Pleurotus florida) on Wheat Straw Supplemented with Wheat and Rice Brans. Int.J.Curr.Microbiol.App.Sci. 9(12): 2324-2328. doi: https://doi.org/10.20546/ijcmas.2020.912.275 